\title{
(Pro)renin Receptor Contributes to Hypoxia/Reoxygenation-Induced Apoptosis and Autophagy in Myocardial Cells via the $\beta$-Catenin Signaling Pathway
}

\author{
Xin GAO ${ }^{1}$, Shenglin ZHANG ${ }^{2}$, Dongxia WANG ${ }^{1}$, Yunpeng CHENG ${ }^{1}$, Yinong JIANG ${ }^{1}$, Yan \\ LIU $^{1}$
}

${ }^{1}$ Department of Cardiology, The First Affiliated Hospital of Dalian Medical University, Dalian, Liaoning, People's Republic of China, ${ }^{2}$ Department of General Surgery, The First Affiliated Hospital of Dalian Medical University, Dalian, Liaoning, People's Republic of China

Received May 15, 2019

Accepted February 24, 2020

Epub Ahead of Print May 29, 2020

\section{Summary}

(Pro)renin receptor (PRR) contributes to regulating many physiological and pathological processes; however, the role of PRR-mediated signaling pathways in myocardial ischemia/reperfusion injury (IRI) remains unclear. In this study, we used an in vitro model of hypoxia/reoxygenation $(H / R)$ to mimic IRI and carried out PRR knockdown by siRNA and PRR overexpression using CDNA in H9c2 cells. Cell proliferation activity was examined by MTT and Cell Counting Kit-8 (CCK-8) assays. Apoptosis-related factors, autophagy markers and $\beta$-catenin pathway activity were assessed by real-time PCR and western blotting. After $24 \mathrm{~h}$ of hypoxia followed by $2 \mathrm{~h}$ of reoxygenation, the expression levels of PRR, LC3B-I/II, Beclin1, cleaved caspase-3, cleaved caspase- 9 and Bax were upregulated, suggesting that apoptosis and autophagy were increased in $\mathrm{H} 9 \mathrm{c} 2$ cells. Contrary to the effects of PRR downregulation, the overexpression of PRR inhibited proliferation, induced apoptosis, increased the expression of pro-apoptotic factors and autophagy markers, and promoted activation of the $\beta$-catenin pathway. Furthermore, all these effects were reversed by treatment with the $\beta$-catenin antagonist DKK-1. Thus, we concluded that PRR activation can trigger $\mathrm{H} / \mathrm{R}$-induced apoptosis and autophagy in $\mathrm{H} 9 \mathrm{C} 2$ cells through the $\beta$-catenin signaling pathway, which may provide new therapeutic targets for the prevention and treatment of myocardial IRI.

\section{Key words}

PRR - Hypoxia/reoxygenation - Apoptosis - Autophagy • $\beta$-catenin signaling pathway

\section{Corresponding author}

Y. Liu, Department of Cardiology, The First Affiliated Hospital of Dalian Medical University, 193 Lianhe Road, Dalian, Liaoning 116001, People's Republic of China. Fax: +86-411-836359632141. E-mail: liuyanjulie@outlook.com

\section{Introduction}

Myocardial infarction (MI) leads to deaths worldwide and places a tremendous burden on individuals and society (Benjamin et al. 2017). Blockade of the coronary artery completely or partially deprives the downstream tissue of oxygen and nutrients. Timely and effective reperfusion therapy (emergency percutaneous coronary intervention, thrombolysis or coronary artery bypass surgery) can reduce acute myocardial injury and limit the MI area. However, the resumption of oxygen delivery triggers a second wave of insult, termed reperfusion injury (Yellon and Hausenloy 2007). Myocardial ischemia/reperfusion injury (IRI) has been reported to attenuate the benefit of reperfusion and lead to cardiac failure and arrhythmia. Thus, there is great interest in identifying the mechanisms of IRI in the hopes of mitigating this damage. However, the pathophysiological mechanism of IRI has not been elucidated in detail. Many factors, especially cell apoptosis and autophagy, are involved in the pathogenesis of IRI.

The renin-angiotensin (Ang) system (RAS) is

PHYSIOLOGICAL RESEARCH • ISSN 1802-9973 (online) 
a hormonal system that regulates blood pressure by affecting vasomotor tone and salt and fluid retention. The RAS is also involved in IRI, and Ang II levels are elevated in the damaged myocardium (Zhu et al. 2000, Yahiro et al. 2003, Dogan et al. 2001). (Pro)renin receptor (PRR), a new member of the RAS, was discovered and cloned from the mesangium of glomeruli by Nguyen in 2002 (Nguyen et al. 2002). Both renin and PR bind PRR, which not only catalyzes the production of active Ang II but also activates an intracellular signal pathway independent of Ang II formation (Zhou et al. 2010, Kouchi et al. 2017, Krop et al. 2013). Accumulating evidence has shown that PRR is activated in hypertension and cardiovascular and renal diseases. Furthermore, data have shown that PRR is expressed at high levels in neurons for the central control of blood pressure, the heart in patients with dilated cardiomyopathy, and chronic kidney disease patients (Nguyen 2011, Mahmud et al. 2012, Hamada et al. 2013, Ramkumar et al. 2018).

$\beta$-catenin signaling, which plays a vital role in the progression of several diseases, is involved in regulating cell survival/apoptosis in different cell types, including cardiomyocytes (Ding et al. 2000, Fukumoto et al. 2001). Moreover, the $\beta$-catenin signaling pathway contributes to cell autophagy in adipogenesis (Romero et al. 2018) and human tumor cell lines (Hou et al. 2018, $\mathrm{Hu}$ et al. 2019). In addition, PRR, acting as a specific adaptor, is involved in Wnt/ $\beta$-catenin signaling (Cruciat et al. 2010). Therefore, we hypothesized that PRR can affect cell autophagy and apoptosis in IRI in cardiomyocytes via the activation of $\beta$-catenin signaling.

Despite the previous finding that PRR activation could trigger the H/R-induced apoptosis of $\mathrm{H} 9 \mathrm{c} 2$ cells through the p38 MAPK/caspase-3 signaling pathway (Liu et al. 2015), the association between PRR and $\beta$-catenin signaling in IRI is unclear. $\mathrm{H} 9 \mathrm{c} 2$ is an original clonal cell line derived from embryonic BD1X rat heart tissue by B. Kimes and B. Brandt. We illustrated the molecular mechanism underlying the regulatory effects of PRR associated with $\beta$-catenin signaling on $\mathrm{H} / \mathrm{R}$-induced apoptosis and autophagy in $\mathrm{H} 9 \mathrm{c} 2$ cells. Additionally, in vitro studies were beneficial in excluding the effects of nerves, body fluids and the interactions between cardiomyocytes. In the present study, we established an in vitro model of $\mathrm{H} / \mathrm{R}$ using $\mathrm{H} 9 \mathrm{c} 2$ cells and transfected specific siRNAs or a recombinant plasmid encoding PRR into the cells to knock down or overexpress PRR, respectively. In addition, we examined key genes related to the $\beta$-catenin pathway. Finally, we treated H9c2 cells with the $\beta$-catenin antagonist DKK-1 to investigate the role of $\mathrm{PRR}$ in $\beta$-catenin signaling in $\mathrm{H} 9 \mathrm{c} 2$ cells after $\mathrm{H} / \mathrm{R}$.

\section{Materials and Methods}

\section{Cell culture and transfection}

$\mathrm{H} 9 \mathrm{c} 2$ cells were obtained from Zhong Qiao Xin Zhou Biotechnology Co., Ltd. (Shanghai, China) and cultured in DMEM (Gibco, Grand Island, NY, USA) supplemented with $10 \%$ fetal bovine serum (FBS) (HyClone, Logan, UT, USA) in $5 \% \mathrm{CO}_{2}$ in air at $37{ }^{\circ} \mathrm{C}$. $\mathrm{H} 9 \mathrm{c} 2$ cells were prepared by treatment with $10 \mu \mathrm{mol} / 1$ valsartan (MCE, USA) (Angiotensin II receptor 1 blocker) and $20 \mu \mathrm{mol} / 1 \quad$ PD123319 (Selleck, USA) (Angiotensin II receptor 2 blocker). The siRNA sequences were as follows: siRNA-1, 5'-GCGAAUGAAUUUAGCAUAU-3'; siRNA-2: 5'GCUGCAUGAUAUUUCAAGU-3'; and siRNA-3: 5'CCUUGCGUAUAAGUAUAAU-3'. The PRR coding sequence was inserted into the pcDNA3.1 plasmid (Clontech, Palo Alto, CA, USA) as previously reported (Peng et al. 2018). Cell transfection was performed with Lipofectamine 2000 (Invitrogen, CA, USA) according to the manufacturer's instructions. For DKK-1 treatment, cells were treated with $20 \mathrm{ng} / \mathrm{ml}$ DKK-1 (Sino Biological, Beijing, China) for $2 \mathrm{~h}$ before transfection. For $\mathrm{H} / \mathrm{R}$ treatment, cells were treated with $24 \mathrm{~h}$ hypoxia $\left(1 \% \mathrm{O}_{2}, 5 \% \mathrm{CO}_{2}\right.$, and $\left.94 \% \mathrm{~N}_{2}\right)$, followed by $2 \mathrm{~h}$ of reoxygenation $\left(5 \% \quad \mathrm{CO}_{2}, \quad 37^{\circ} \mathrm{C}\right)$ at $48 \mathrm{~h}$ after transfection.

\section{MTT assay}

Cells were seeded in 96-well plates at a density of $3 \times 10^{3} /$ well, and after incubation under normoxia or $\mathrm{H} / \mathrm{R}$ treatment, a $5 \mathrm{mg} / \mathrm{ml}$ MTT solution (Wanleibio, Shenyang, China) was added, and cells were incubated for $4 \mathrm{~h}$. The supernatant was then removed and replaced with $200 \mu$ of dimethylsulfoxide (DMSO, Sigma, St. Louis, MO, USA) to dissolve the blue-purple formazan crystals. The absorbance at $490 \mathrm{~nm}$ was then measured using a microplate reader (ELx800, BioTek Instruments, VT, USA).

\section{Real-time PCR}

mRNA expression was detected by real-time PCR. Total RNA was extracted with an RNA pure total RNA kit (BioTek, Beijing, China) according to the manufacturer's instructions. RNA was quantified, and 
then $1 \mu \mathrm{g}$ of total RNA from each sample was used for cDNA synthesis with Super M-MLV reverse transcriptase (BioTek). The cDNA product was subsequently subjected to real-time PCR with a SYBR Green kit (Solarbio, Beijing, China). $\beta$-actin was used as a reference gene for the normalization of mRNA expression levels. RNA expression was calculated with the $2^{-\Delta \Delta \mathrm{Ct}}$ method. Sequences of the primers used in this study are presented in Table 1 .

Table 1. Sequences of primers used for real-time PCR.

\section{Primer name}

\section{PRR F}

PRR R

beclin1 F

beclin1 $R$

$\operatorname{Bax} F$

$\operatorname{Bax} R$

Bcl-2 F

Bcl-2 R

$\beta$-actin $F$

$\beta$-actin $R$
Sequence (5'-3')

CGAGTGCTTTAGCGAATGAA
GAGCCAGTTTATCTACCCCC
TGCGTCAGCTCTCGTCAAG
ACCTCCAGAGTTCCCATCGC
GGCGAATTGGAGATGAACTGGAC
GCAAAGTAGAAGAGGGCAACCAC
ATGCGACCTCTGTTTGATTTCTC
AACTTTGTTTCATGGTCCATCCT
CACTGTGCCCATCTACGAGG
TAATGTCACGCACGATTTCC

1:10000, Proteintech) for $40 \mathrm{~min}$ at room temperature. Protein bands were visualized using an ECL kit (7 Sea Biotech, Shanghai, China).

Flow cytometry

Flow cytometry was performed to detect the cell apoptosis status. Cells were collected by centrifugation $(309 \times \mathrm{g})$ for $5 \mathrm{~min}$. Thereafter, the cells were washed twice with phosphate-buffered saline (PBS). Next, $5 \mu \mathrm{l}$ of Annexin V-FITC and $10 \mu \mathrm{l}$ of propidium iodide were added to each sample and mixed well. Finally, the cells were incubated at room temperature for $15 \mathrm{~min}$ and then analyzed by flow cytometry.

\section{CCK-8 assay}

Cells were seeded in 96-well plates at a density of $3 \times 10^{3} /$ well, and $10 \mu \mathrm{l}$ of CCK- 8 reagent (Wanleibio) was added to each well and incubated in $5 \% \mathrm{CO}_{2}$ at $37^{\circ} \mathrm{C}$ for $1 \mathrm{~h}$. Then, the $\mathrm{OD}$ value at $450 \mathrm{~nm}$ was determined with a microplate reader (ELx800, BioTek, VT, USA).

\section{Statistical analysis}

Data are expressed as the mean \pm standard deviation (SD) and were analyzed using the unpaired Student's $t$-test or one-way analysis of variance (ANOVA) with GraphPad Prism 5.0 software (GraphPad Software, Inc., San Diego, CA, USA). $p<0.05$ indicated significant differences. 


\section{Results}

\section{$H / R$ induced apoptosis and autophagy in $H 9 c 2$ cells}

To investigate $\mathrm{H} / \mathrm{R}$-induced apoptosis in $\mathrm{H} 9 \mathrm{c} 2$ cells, we first examined cell viability by the MTT assay. The cell viability after $\mathrm{H} / \mathrm{R}$ was decreased by $23.89 \%$ compared to control cells (Fig. 1A). Furthermore, cell apoptosis was detected by flow cytometry, the results of which suggested that the apoptosis rate of cells treated with $\mathrm{H} / \mathrm{R}$ was remarkably higher than that of the control cells (14.31\% vs. $7.58 \%$, respectively) (Fig. 1B). Moreover, the mRNA levels of PRR, Beclin1, Bax and Bcl-2 were assessed by real-time PCR, which showed that the mRNA levels of PRR, Beclin1 and Bax were significantly increased, while the Bcl-2 mRNA level was decreased by $\mathrm{H} / \mathrm{R}$ treatment in $\mathrm{H} 9 \mathrm{c} 2$ cells compared to control cells (Fig. 1C). Finally, the expression levels of PRR, LC3BI/II, Beclin1, cleaved caspase-3, cleaved caspase-9, Bax and Bcl-2 were measured by western blotting, the results of which suggested that the expression levels of PRR, LC3BI/II, Beclin1, cleaved caspase-3, cleaved caspase-9 and Bax were increased in cells after $\mathrm{H} / \mathrm{R}$, while the $\mathrm{Bcl}-2$ expression level was decreased compared to that in control cells (Fig. 1D), similar to the real-time PCR results.
A

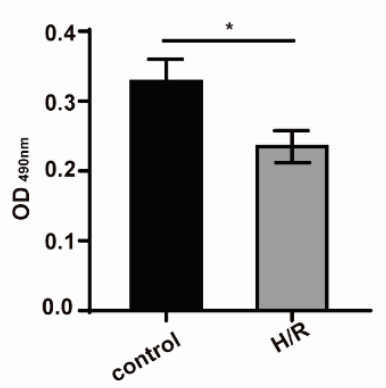

B

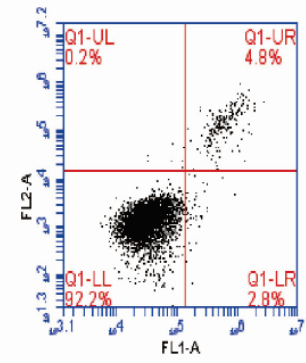

D

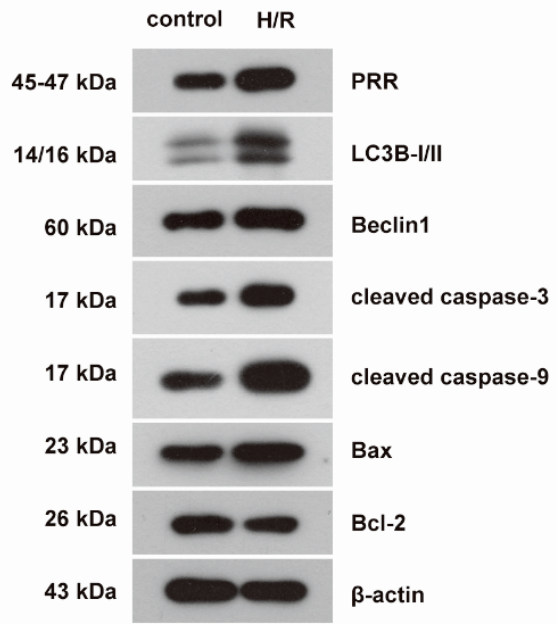

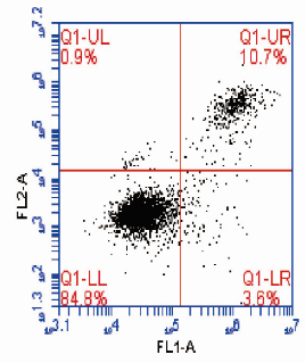

C

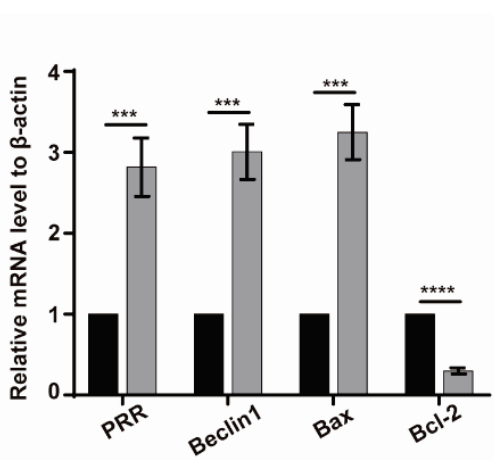

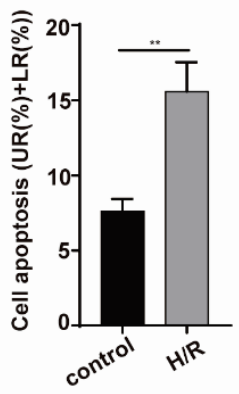

Control

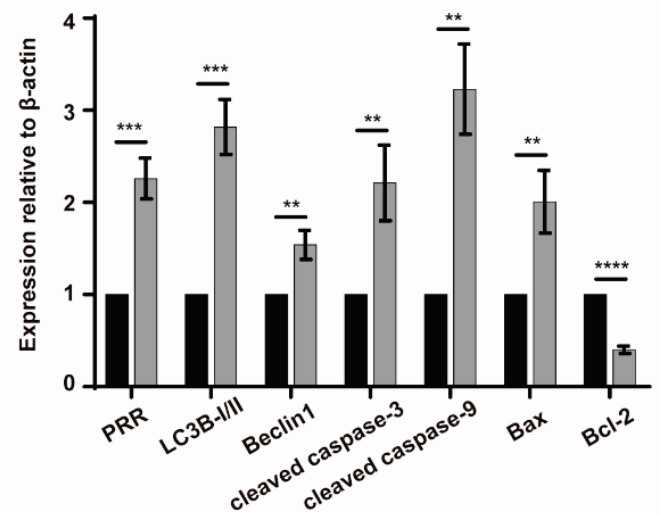

Fig. 1. $H / R$ induced autophagic activity and apoptosis in $H 9 c 2$ cells. (A) $H 9 c 2$ cells were treated with (called $H / R$ ) or without (called control) hypoxia $\left(1 \% \mathrm{O}_{2}, 5 \% \mathrm{CO}_{2}\right.$, and $\left.94 \% \mathrm{~N}_{2}\right)$ for $24 \mathrm{~h}$, followed by reoxygenation $\left(5 \% \mathrm{CO}_{2}, 37^{\circ} \mathrm{C}\right)$ for $2 \mathrm{~h}$. $\mathrm{H} 9 \mathrm{c} 2$ cell viability was measured at $490 \mathrm{~nm}$ using the MTT method. (B) Apoptosis of control and H/R cells (UR (\%) + LR (\%)) was measured with an apoptosis assay kit. (C) The mRNA levels of PRR, Beclin1, Bax and Bcl2 were determined by real-time PCR. (D) The protein levels of PRR, LC3B-I/II, Beclin1, cleaved caspase-3, cleaved caspase-9, Bax and Bcl-2 were analyzed using western blotting. Data are expressed as the mean \pm standard deviation (SD) and were analyzed using the unpaired Student's t-test or one-way ANOVA $(n=3) . * p<0.05$, ** $p<0.01, * * * p<0.001, * * * * p<0.0001$. 
The expression of PRR in $H 9 c 2$ cells was reduced by siRNA

To explore the effect of PRR in H9c2 cells after $\mathrm{H} / \mathrm{R}$, endogenous PRR was knocked down in H9c2 cells with three siRNAs: siRNA-1, siRNA-2 and siRNA-3. As shown in Fig. 2A and B, the mRNA and protein levels of PRR were significantly decreased in siRNA-transfected cells compared to standard negative control
(NC)-transfected cells, suggesting that PRR was efficiently silenced. Moreover, the mRNA and protein levels of PRR in siRNA-1-transfected cells were the lowest, suggesting that siRNA-1 was the most efficient in silencing PRR among the three siRNAs. Therefore, siRNA-1, which inhibited the PRR mRNA level by $72 \%$ and the PRR protein level by $69 \%$, was chosen for further experiments.
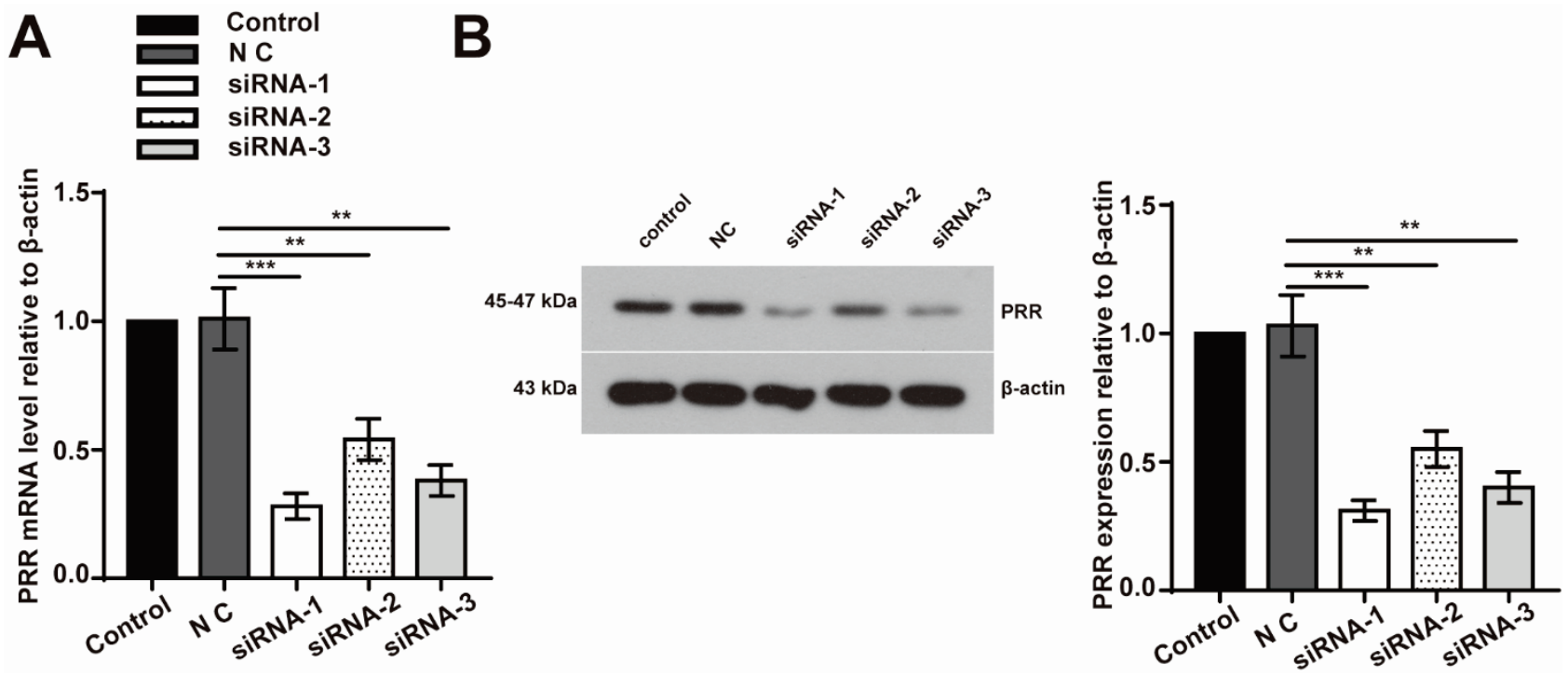

Fig. 2. PRR expression was most effectively silenced in H9c2 cells transfected with siRNA-1. (A) After transfection with siRNA-1, siRNA-2 or siRNA-3, the mRNA levels of PRR in H9c2 cells were determined by real-time PCR. (B) The expression level of PRR was assessed by western blotting. Data are expressed as the mean \pm standard deviation (SD) and were analyzed using one-way ANOVA $(\mathrm{n}=3) . * * p<0.01, * * * p<0.001$.

Overexpression of PRR aggravated H/R-induced cell autophagy and apoptosis

To investigate the function of PRR in H/R-treated H9c2 cells, an expression plasmid encoding PRR was transfected into H9c2 cells to overexpress PRR before $H / R$ treatment, and cell proliferation and the apoptosis status were detected by CCK- 8 and flow cytometry assays, respectively. According to the results, PRR downregulation significantly promoted cell proliferation and suppressed apoptosis in H9c2 cells, whereas the overexpression of PRR inhibited proliferation and induced apoptosis in $\mathrm{H} 9 \mathrm{c} 2$ cells (Fig. 3A and B). The expression levels of apoptosis and autophagy-related factors were also examined by realtime PCR and western blotting. As shown in Fig. 3C and $\mathrm{D}$, expression levels of the proapoptotic factors cleaved caspase-3, cleaved caspase-9 and Bax as well as the autophagy markers LC3B-I/II and Beclin-1 were markedly reduced by the knockdown of PRR and increased by the overexpression of PRR. Moreover, Bcl-2, an antiapoptotic factor, was increased by PRR knockdown and inhibited by PRR overexpression.

Furthermore, to investigate whether the expression of PRR affects the $\beta$-catenin pathway, we examined the expression of Dvl-1 and $\beta$-catenin by western blotting. As shown in Fig. 3E, the expression levels of Dvl-1 and nuclear $\beta$-catenin were increased in H9c2 cells overexpressing PRR and decreased in cells in which PRR had been silenced. The expression levels of Dvl-1 and nuclear $\beta$-catenin were increased by $160 \%$ and $67 \%$ in cells overexpressing PRR, respectively, and decreased by $47 \%$ and $60 \%$ in cells in which PRR had been silenced, respectively, compared to the control cells. These results suggested that PRR contributes to $\mathrm{H} / \mathrm{R}$-induced apoptosis and autophagy in H9c2 cells and that these effects of PRR are related to the $\beta$-catenin pathway. 

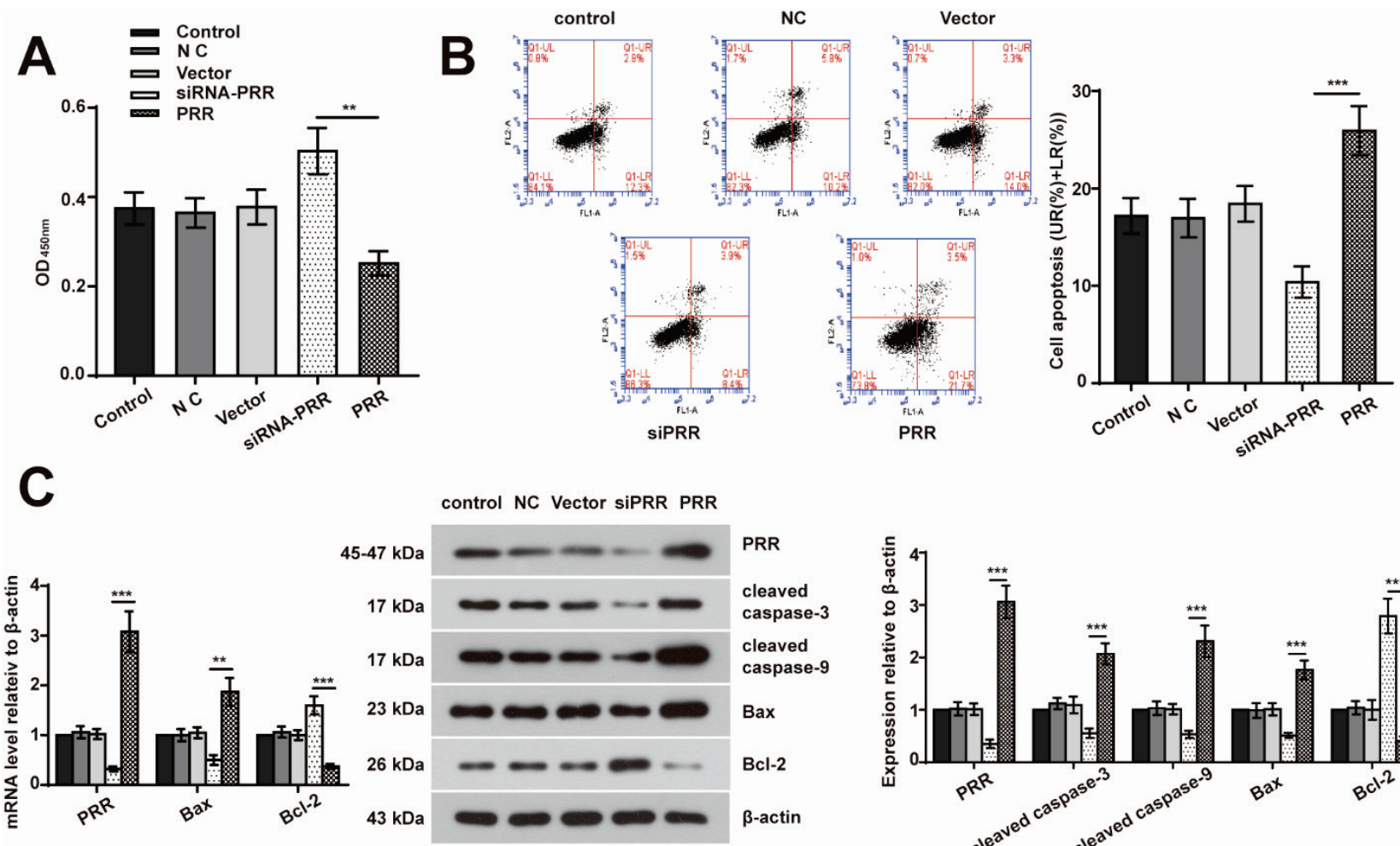

control NC Vector siPRR PRR
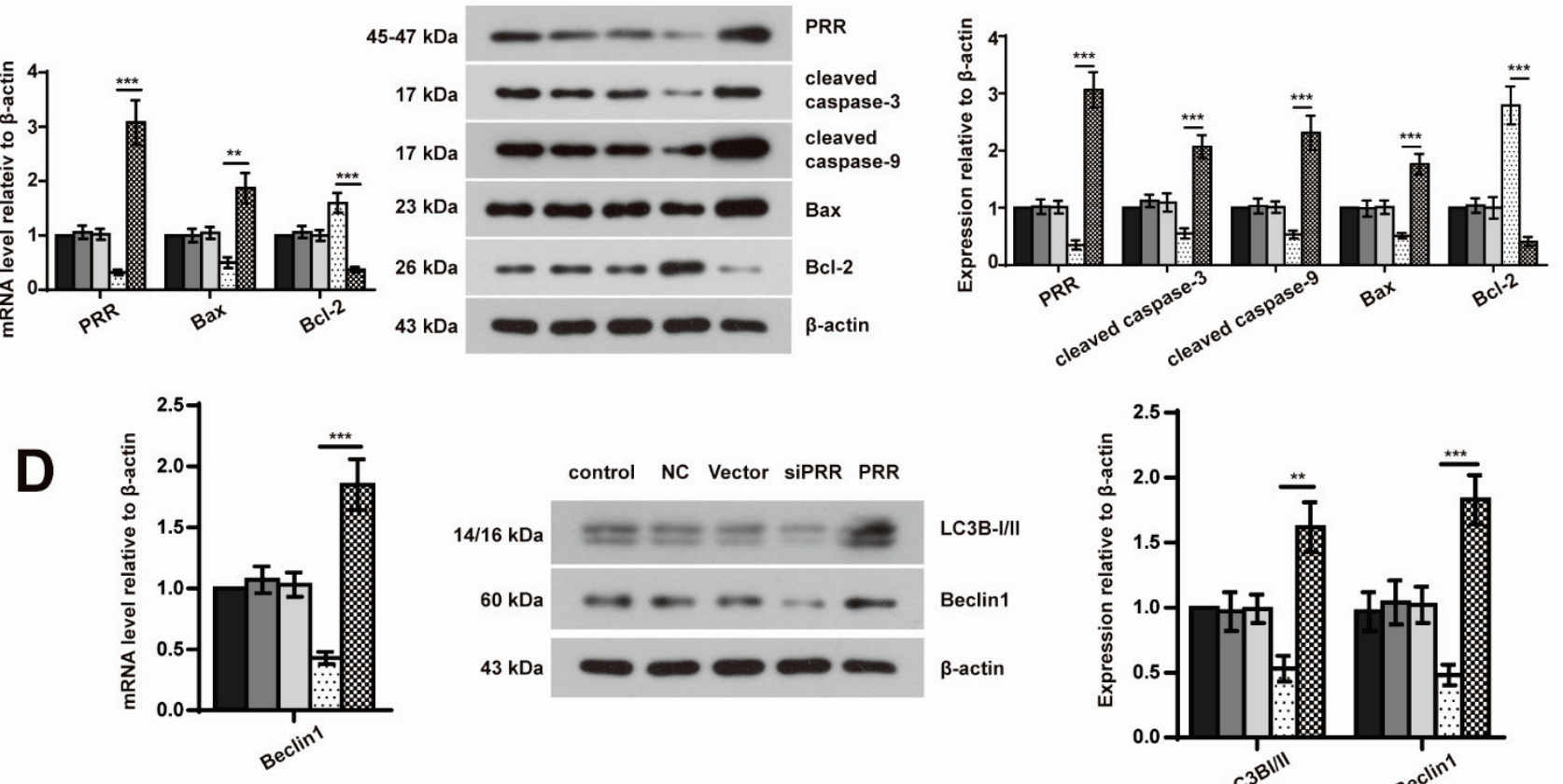

E
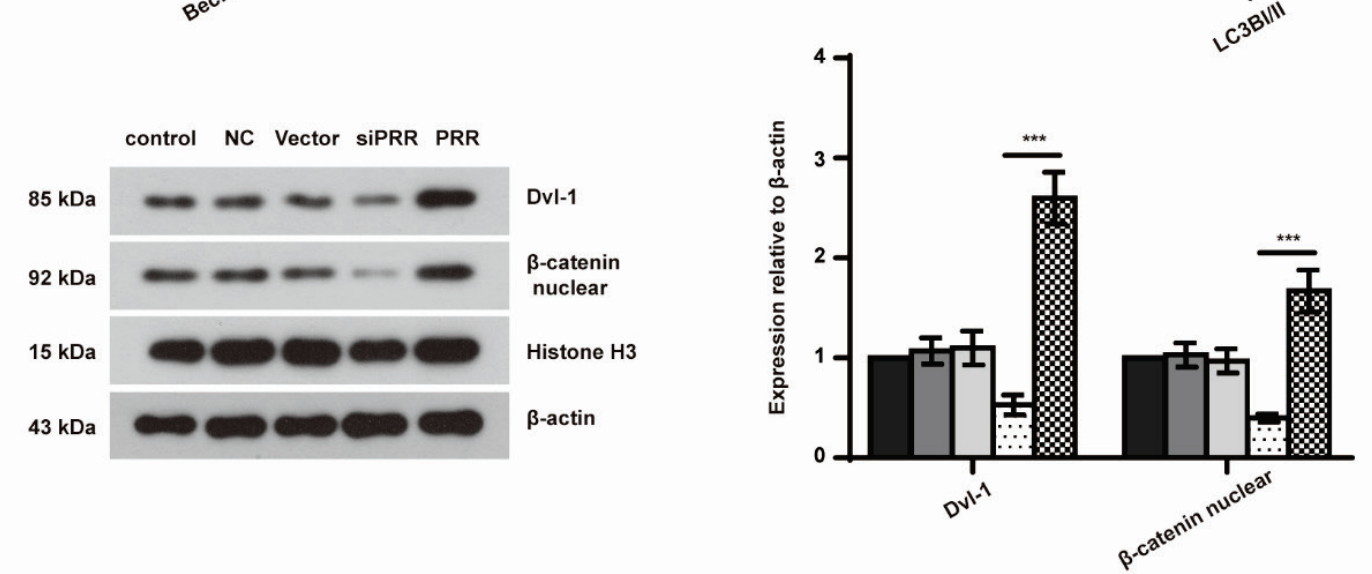

Fig. 3. Overexpression of $P R R$ induced cellular autophagy and apoptosis after $\mathrm{H} / \mathrm{R}$. $\mathrm{H} 9 \mathrm{c} 2$ cells were treated with hypoxia $\left(1 \% \mathrm{O}_{2}, 5 \%\right.$ $\mathrm{CO}_{2}$, and $\left.94 \% \mathrm{~N}_{2}\right)$ for $24 \mathrm{~h}$, followed by reoxygenation $\left(5 \% \mathrm{CO}_{2}, 37{ }^{\circ} \mathrm{C}\right)$ for $2 \mathrm{~h}$. Cell proliferation $(\mathbf{A})$ and apoptosis (B) were detected by CCK-8 and flow cytometry assays, respectively. Cell proliferation (A) was decreased, and apoptosis (B) was increased by PRR overexpression in H9c2 cells compared to siRNA-mediated PRR knockdown cells. (C) Detection of cell apoptosis-related genes. The mRNA levels of PRR, Bax and Bcl-2 were determined by real-time PCR, and the expression levels of PRR, cleaved caspase-3, cleaved caspase-9, Bax and BCl-2 were assessed by western blotting. (D) The mRNA level of Beclin1 and the expression levels of LC3B-I/II and Beclin1 were detected by real-time PCR and western blotting, respectively. (E) The expression levels of Dvl-1 and nuclear $\beta$-catenin were determined by western blotting. Data are expressed as the mean \pm standard deviation (SD) and were analyzed using one-way ANOVA $(\mathrm{n}=3)$. ** $p<0.01, * * * p<0.001$. 
Deactivation of the $\beta$-catenin pathway depressed $H / R$ induced cell apoptosis and autophagy mediated by PRR

To confirm the association between the $\beta$-catenin pathway and PRR-induced cell apoptosis as well as autophagy, we added $20 \mathrm{ng} / \mathrm{ml}$ DKK-1, a $\beta$-catenin antagonist, to $\mathrm{H} 9 \mathrm{c} 2$ cells before their transfection and $H / R$ treatment. As expected, the PRR-mediated inhibition of proliferation was reversed by treatment with DKK-1 (Fig. 4A), and proliferation was increased by $44.53 \%$ in PRR+DKK-1 cells compared to PRR cells. PRR-induced cell apoptosis was abolished by treatment with DKK-1 (Fig. 4B), and the apoptosis rate was decreased by $22.44 \%$ in PRR+DKK-1 cells compared to PRR-overexpressing cells. This effect was also confirmed by changes in the expression of apoptosisrelated factors (Fig. 4C). Furthermore, treatment with the $\beta$-catenin antagonist blocked the PRR-induced upregulation of the autophagy markers LC3-BI/II and Beclin-1 (Fig. 4D). All the results provide evidence to confirm that deactivation of the $\beta$-catenin pathway can depress PRR expression and then inhibit H/R-induced cell autophagy and apoptosis.
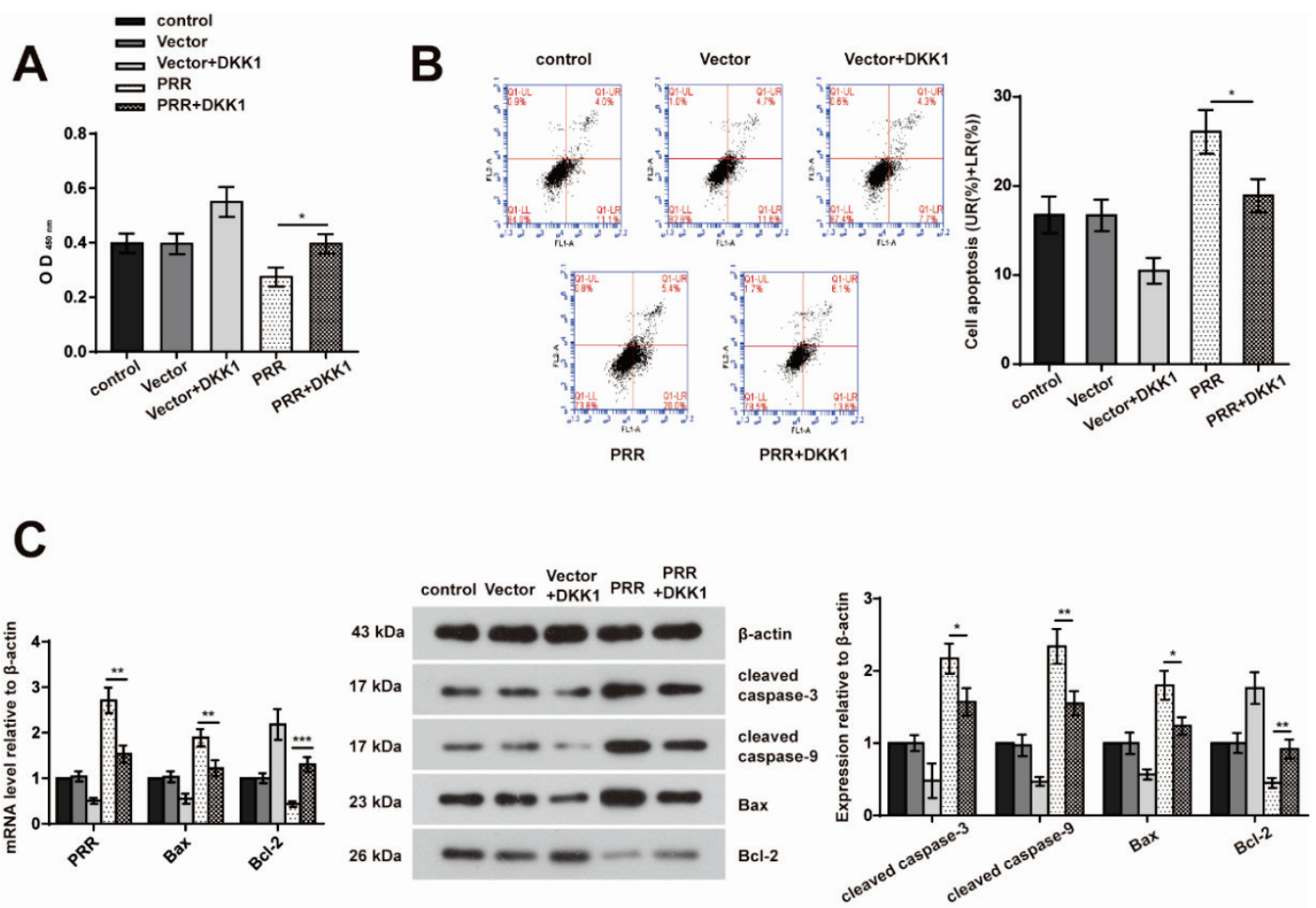

D
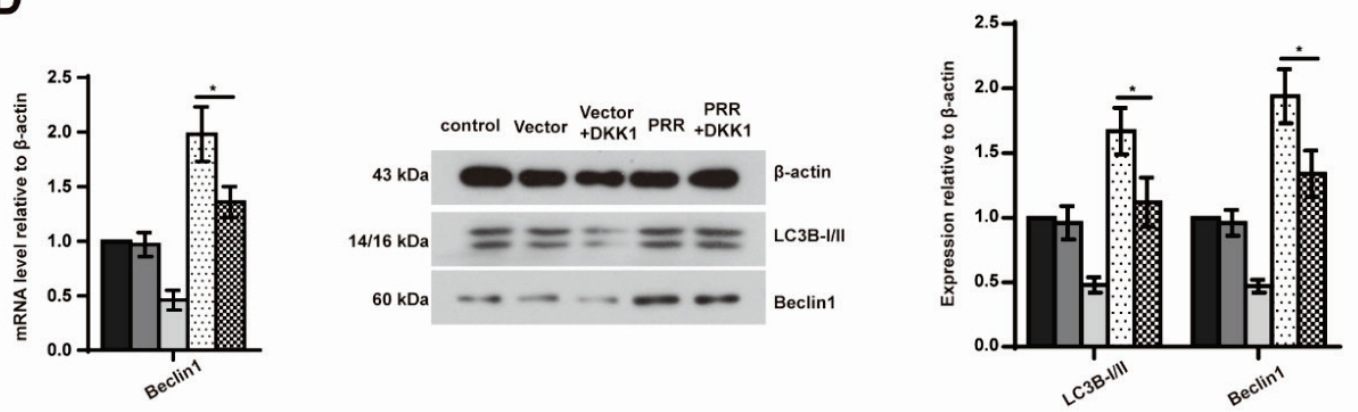

Fig. 4. Deactivation of the $\beta$-catenin pathway depressed PRR-induced cell autophagy and apoptosis after $H / R$. H9c2 cells were prepared by treatment with $10 \mu \mathrm{mol} / \mathrm{l}$ valsartan and $20 \mu \mathrm{mol} / \mathrm{l} \mathrm{PD123319}$. Then, the cells were treated with or without $20 \mathrm{ng} / \mathrm{ml}$ DKK-1 before their transfection. After transfection, the cells were subjected to $\mathrm{H} / \mathrm{R}$ treatment. Cell proliferation (A) and apoptosis (B) were detected by CCK-8 and flow cytometry assays, respectively. Cell proliferation (A) was increased, and apoptosis (B) was decreased in H9c2 cells treated with DKK-1 compared with cells without DKK-1 treatment. (C) The mRNA levels of PRR, Bax and Bcl-2 were determined by realtime PCR. Moreover, the expression levels of cleaved caspase-3, cleaved caspase-9, Bax and BCl-2 were assessed by western blotting. (D) The mRNA level of Beclin1 and the expression levels of LC3B-I/II and Beclin1 were detected by real-time PCR and western blotting, respectively. Data are expressed as the mean \pm standard deviation (SD) and were analyzed using one-way ANOVA $(n=3) . * p<0.05$, $* * p<0.01, * * * p<0.001$. 


\section{Discussion}

In this study, we found that $H / R$ increased apoptosis and autophagy in H9c2 cells. To the best of our knowledge, this study is the first to demonstrate that PRR mediates the apoptosis and autophagy of cardiomyocytes induced by $\mathrm{H} / \mathrm{R}$ via activating the $\beta$-catenin signaling pathway.

Acute IRI results in cardiomyocyte death, cardiac failure, and arrhythmias and increases 30-day patient mortality rates (Zhou et al. 2017). The mechanism of myocardial IRI is complex and has not been fully elucidated. Additionally, cell apoptosis and autophagy may play pivotal roles in the pathogenesis of IRI. Autophagy-related gene expression was found to be activated in the human myocardium after acute IRI (Singh et al. 2014). In addition, cardiomyocyte cell death in IRI is critical to the progression of IRI and probably related to specific signal transduction mechanisms (Ibanez et al. 2015). Furthermore, PRR overexpression has been associated with hypertension, diabetes, heart failure, proteinuria, and nephropathy. In addition, PRR has been reported to promote kidney fibrosis and injury through amplifying Wnt/ $\beta$-catenin signaling ( $\mathrm{Li}$ et al. 2017). Moreover, PRR silencing attenuated activation of the $\beta$-catenin signaling pathway, reduced proliferation and induced apoptosis in pancreatic ductal adenocarcinoma cells in vitro (Shibayama et al. 2015). However, the role of $\mathrm{Wnt} / \beta$-catenin signaling mediated by PRR in IRI has not been well studied thus far. Therefore, we used an in vitro $\mathrm{H} / \mathrm{R}$ model to mimic IRI in vivo and demonstrated the effects of PRR and Wnt/ $\beta$-catenin signaling on apoptosis and autophagy under $\mathrm{H} / \mathrm{R}$ in vitro. We first added Ang II receptor blockers to avoid the influence of Ang II.

Cardiomyocyte apoptosis plays vital roles in the progression of myocardial disorders, including IRI. Furthermore, high glucose was found to decrease autophagy and increases apoptosis in mouse podocytes through the PRR signaling pathway (Li and Siragy 2015). Detection of apoptosis-related proteins by flow cytometric analysis showed that the overexpression of PRR downregulated the expression of the antiapoptotic protein $\mathrm{Bcl}-2$ and promoted the activation of cleaved caspase-3 and cleaved caspase-9, thereby inducing apoptosis. These findings suggest that cell apoptosis induced by $\mathrm{H} / \mathrm{R}$ can be enhanced by PRR overexpression and depressed by PRR silencing in H9c2 cells. Consistent with the results of flow cytometric and western blot analyses, the effect of PRR overexpression in promoting cardiomyocyte autophagy was also demonstrated in H/R-treated H9c2 cells. Autophagy is a bulk protein and organelle degradation process (Matsui et al. 2007). PRR has been reported to play a vital role in regulating the maintenance of cellular homeostasis via autophagyrelated signaling pathways (Binger and Muller 2013). In addition, PRR mediates the function and survival of podocytes by maintaining autophagy (Riediger et al. 2011). In the heart, ischemia/reperfusion stimulates autophagy via a Beclin 1-dependent mechanism (Matsui et al. 2007). In this study, $\mathrm{H} / \mathrm{R}$ induced an increase in the expression of the key autophagy-related genes LC3B-I/II and Beclin1, resulting in autophagy flux. Our results demonstrated the inhibitory effect of PRR knockdown on myocardial apoptosis and autophagy.

PRR has been identified as a crucial player in the $\beta$-catenin signaling pathway (Cruciat et al. 2010). Several studies have confirmed that the $\beta$-catenin signaling pathway contributes to a variety of biological processes, including cell apoptosis and autophagy (MacDonald et al. 2009). In addition, PRR is involved in the RAS and an auxiliary subunit of the V-ATP enzyme and plays an important role in maintaining the intracellular $\mathrm{pH}$. Notably, the increased expression of PRR enhanced $\beta$-catenin activation and augmented the expression of its downstream targets. Conversely, the knockdown of PRR abolished $\beta$-catenin activation (Li et al. 2017). In a mouse model of IRI, transfection with PRR expression vectors promoted $\beta$-catenin activation. PRR overexpression significantly activated the $\beta$-catenin signaling pathway, and PRR silencing deactivated $\beta$-catenin signaling in human kidney proximal tubular cells (HKC-8 cells) (Li et al. 2017). In this study, we found that $\beta$-catenin was activated by PRR overexpression and deactivated by PRR silencing, which is consistent with the results of a previous study in the kidney ( $\mathrm{Li}$ et al. 2017). Dvl positively regulates $\beta$-catenin signaling. Activated Dvl inhibits the degradation of $\beta$-catenin and induces the cytoplasmic accumulation of $\beta$-catenin, which then enters the nucleus to regulate the expression of many downstream genes (Kockeritz et al. 2006, Forde and Dale 2007). Several studies documented potential positive role of $\beta$-catenin in adaptive responses to ischemic (hypoxic) stress, which regulated via GSK3 $\beta$, and GSK3 $\beta$ phosphorylation played a protective role in ischemic preconditioning by increasing the threshold for the oxidative stress-induced transition in mitochondrial permeability (Juhaszova et al. 2004, Thirunavukkarasu 
et al. 2015, Potz et al. 2017). However, the results were not always concordant. Another study showed that preventing GSK3 $\beta$ phosphorylation is unlikely to be the key determinant of the cardioprotective effects of ischemic preconditioning (Nishino et al. 2008). In addition, the study of Barandon et al. (2003) showed the antagonist for the $\mathrm{Wnt} /$ frizzled pathway decreased the cytosolic accumulation of $\beta$-catenin and reduced infarct size. These conflicting results are probably due to the different experimental models, duration of ischemia or infarction, and the modulating complexity of upstream signals of $\beta$-catenin signaling. The present results were obtained on embryonic cardiac muscle cells. We examined the effect of PRR on the expression levels of Dvl-1 and $\beta$-catenin. Increased PRR was found to upregulate the expression of Dvl-1 and $\beta$-catenin and induce cell apoptosis and autophagy caused by $H / R$ in H9c2 cells.

Notably, the relationship between PRR and the $\beta$-catenin pathway was demonstrated in our study by the treatment of $\mathrm{H} 9 \mathrm{c} 2$ cells with an inhibitor of the $\beta$-catenin pathway - DKK-1. DKK-1, a natural antagonist of the Wnt signaling pathway, interrupts the Wnt signaling pathway by directly or indirectly competitively binding a receptor common to Wnt-related proteins. We found that DKK-1 downregulated PRR expression after $\mathrm{H} / \mathrm{R}$ treatment and thereby partially antagonized apoptosis and autophagy induced by PRR. Hence, PRR regulates $\mathrm{H} / \mathrm{R}$-induced apoptosis and autophagy via the $\beta$-catenin pathway. Some experiments on PRR have been conducted in vivo, but the mechanism of PRR remains unknown. Reperfusion strategies for MI may result in paradoxical cardiomyocyte dysfunction, also known as IRI. In a MI rat model, the mRNA level of PRR was remarkably increased (Ribeiro et al. 2018). In an IRI rat model, PRR blockade ameliorated MI and IRI (Ellmers et al. 2016). Moreover, the increased expression of PRR induced cell apoptosis in an IRI rat model (Granado et al. 2014). In PRR knockout mice, the loss of PRR disturbed autophagic flux (Binger and Muller 2013, Kinouchi et al. 2010). Given these experimental results in animal model, we predict that results collected in vivo will be similar to those of previous studies, which provide evidence for the regulatory effects of PRR on cell apoptosis and autophagy in cardiac myocytes. Overall, further research is still required to better understand the function of PRR and its underlying mechanism in cardiomyocytes in vivo.

\section{Conclusions}

In conclusion, PRR regulates $\mathrm{H} / \mathrm{R}$-induced apoptosis and autophagy in cardiomyocytes through activation of the $\beta$-catenin signaling pathway. This study is expected to provide a new therapeutic target for the prevention and treatment of myocardial IRI.

\section{Conflict of Interest}

There is no conflict of interest.

\section{Acknowledgements}

This study was supported by a grant from the National Natural Science Foundation of China (No. 81500304).

\section{References}

BARANDON L, COUFFINHAL T, EZAN J, DUFOURCQ P, COSTET P, ALZIEU P, LEROUX L, MOREAU C, DARE D, DUPLAA C: Reduction of infarct size and prevention of cardiac rupture in transgenic mice overexpressing FrzA. Circulation 108: 2282-2289, 2003. https://doi.org/10.1161/01.cir.0000093186.22847.4c

BENJAMIN EJ, BLAHA MJ, CHIUVE SE, CUSHMAN M, DAS SR, DEO R, DE FERRANTI SD, FLOYD J, FORNAGE M, GILLESPIE C, ISASI CR, JIMENEZ MC, JORDAN LC, JUDD SE, LACKLAND D, LICHTMAN JH, LISABETH L, LIU S, LONGENECKER CT, MACKEY RH, ET AL: Heart Disease and Stroke Statistics-2017 Update: A Report From the American Heart Association. Circulation 135: e146-e603, 2017. https://doi.org/10.1161/cir.0000000000000485

BINGER KJ, MULLER DN: Autophagy and the (Pro)renin receptor. Front Endocrinol (Lausanne) 4: 155, 2013. https://doi.org/10.3389/fendo.2013.00155

CRUCIAT CM, OHKAWARA B, ACEBRON SP, KARAULANOV E, REINHARD C, INGELFINGER D, BOUTROS M, NIEHRS C: Requirement of prorenin receptor and vacuolar H+-ATPase-mediated acidification for Wnt signaling. Science 327: 459-463, 2010. https://doi.org/10.1126/science.1179802

DING VW, CHEN RH, MCCORMICK F: Differential regulation of glycogen synthase kinase 3beta by insulin and Wnt signaling. J Biol Chem 275: 32475-32481, 2000. https://doi.org/10.1074/jbc.m005342200 
DOGAN R, FARSAK B, ISBIR S, SARIGUL A, TUNCER M, KILINC K: Protective effect of lisinopril against ischemia-reperfusion injury in isolated guinea pig hearts. J Cardiovasc Surg (Torino) 42: 43-48, 2001. https://doi.org/10.1080/00365519850186698

ELLMERS LJ, RADEMAKER MT, CHARLES CJ, YANDLE TG, RICHARDS AM: (Pro)renin receptor blockade ameliorates cardiac injury and remodeling and improves function after myocardial infarction. J Card Fail 22: 64-72, 2016. https://doi.org/10.1016/j.cardfail.2015.08.341

FORDE JE, DALE TC: Glycogen synthase kinase 3: a key regulator of cellular fate. Cell Mol Life Sci 64: 1930-1944, 2007. https://doi.org/10.1007/s00018-007-7045-7

FUKUMOTO S, HSIEH CM, MAEMURA K, LAYNE MD, YET SF, LEE KH, MATSUI T, ROSENZWEIG A, TAYLOR WG, RUBIN JS, PERRELLA MA, LEE ME: Akt participation in the Wnt signaling pathway through Dishevelled. J Biol Chem 276: 17479-17483, 2001. https://doi.org/10.1074/jbc.c000880200

GRANADO M, FERNÁNDEZ N, MONGE L, CARRENO-TARRAGONA G, FIGUERAS JC, AMOR S, GARCIAVILLALON AL: Long-term effects of early overnutrition in the heart of male adult rats: role of the reninangiotensin system. PLoS One 8: e65172, 2014. https://doi.org/10.1371/journal.pone.0065172

HAMADA K, TANIGUCHI Y, SHIMAMURA Y, INOUE K, OGATA K, ISHIHARA M, HORINO T, FUJIMOTO S, OHGURO T, YOSHIMOTO Y, IKEBE M, YUASA K, HOSHINO E, IIYAMA T, ICHIHARA A, TERADA Y: Serum level of soluble (pro)renin receptor is modulated in chronic kidney disease. Clin Exp Nephrol 17: 848-856, 2013. https://doi.org/10.1007/s10157-013-0803-y

HOU S, TIAN T, QI D, SUN K, YUAN Q, WANG Z, QIN Z, WU Z, CHEN Z, ZHANG J: S100A4 promotes lung tumor development through beta-catenin pathway-mediated autophagy inhibition. Cell Death Dis 9: $277,2018$. https://doi.org/10.1038/s41419-018-0319-1

HU P, KE C, GUO X, REN P, TONG Y, LUO S, HE Y, WEI Z, CHENG B, LI R, LUO J, MENG Z: Both glypican3/Wnt/beta-catenin signaling pathway and autophagy contributed to the inhibitory effect of curcumin on hepatocellular carcinoma. Dig Liver Dis 51: 120-126, 2019. https://doi.org/10.1016/j.dld.2018.06.012

IBANEZ B, HEUSCH G, OVIZE M, VAN DE WERF F: Evolving therapies for myocardial ischemia/reperfusion injury. J Am Coll Cardiol 65: 1454-1471, 2015. https://doi.org/10.1016/j.jacc.2015.02.032

JUHASZOVA M, ZOROV DB, KIM SH, PEPE S, FU Q, FISHBEIN KW, ZIMAN BD, WANG S, YTREHUS K, ANTOS CL, OLSON EN, SOLLOTT SJ: Glycogen synthase kinase-3beta mediates convergence of protection signaling to inhibit the mitochondrial permeability transition pore. J Clin Invest 113: 1535-1549, 2004. https://doi.org/10.1172/jci19906

KINOUCHI K, ICHIHARA A, SANO M, SUN-WADA GH, WADA Y, KURAUCHI-MITO A, BOKUDA K, NARITA T, OSHIMA Y, SAKODA M, TAMAI Y, SATO H, FUKUDA K, ITOH H: The (pro)renin receptor/ATP6AP2 is essential for vacuolar H+-ATPase assembly in murine cardiomyocytes. Circ Res 107: 30-34, 2010. https://doi.org/10.1161/circresaha.110.224667

KOCKERITZ L, DOBLE B, PATEL S, WOODGETT JS: Glycogen synthase kinase-3--an overview of an over-achieving protein kinase. Curr Drug Targets 7: 1377-1388, 2006. https://doi.org/10.2174/1389450110607011377

KOUCHI M, SHIBAYAMA Y, OGAWA D, MIYAKE K, NISHIYAMA A, TAMIYA T: (Pro)renin receptor is crucial for glioma development via the Wnt/beta-catenin signaling pathway. J Neurosurg 127: 819-828, 2017. https://doi.org/10.3171/2016.9.jns16431

KROP M, LU X, DANSER AH, MEIMA ME: The (pro)renin receptor. A decade of research: what have we learned? Pflugers Arch 465: 87-97, 2013. https://doi.org/10.1007/s00424-012-1105-Z

LI C, SIRAGY HM: (Pro)renin receptor regulates autophagy and apoptosis in podocytes exposed to high glucose. Am J Physiol Endocrinol Metab 309: E302-E310, 2015. https://doi.org/10.1152/ajpendo.00603.2014

LI Z, ZHOU L, WANG Y, MIAO J, HONG X, HOU FF, LIU Y: (Pro)renin receptor is an amplifier of Wnt/betacatenin signaling in kidney injury and fibrosis. J Am Soc Nephrol 28: 2393-2408, 2017. https://doi.org/10.1681/asn.2016070811

LIU Y, ZHANG S, SU D, LIU J, CHENG Y, ZOU L, LI W, JIANG Y: Inhibiting (pro)renin receptor-mediated p38 MAPK signaling decreases hypoxia/reoxygenation-induced apoptosis in H9c2 cells. Mol Cell Biochem 403: 267-276, 2015. https://doi.org/10.1007/s11010-015-2356-8 
MACDONALD BT, TAMAI K, HE X: Wnt/beta-catenin signaling: components, mechanisms, and diseases. Dev Cell 17: 9-26, 2009. https://doi.org/10.1016/j.devcel.2009.06.016

MAHMUD H, SILLJE HH, CANNON MV, VAN GILST WH, BOER RA: Regulation of the (pro)renin-renin receptor in cardiac remodelling. J Cell Mol Med 16: 722-729, 2012. https://doi.org/10.1111/j.1582-4934.2011.01377.x

MATSUI Y, TAKAGI H, QU X, ABDELlATIF M, SAKODA H, ASANO T, LEVINE B, SADOSHIMA J: Distinct roles of autophagy in the heart during ischemia and reperfusion: roles of AMP-activated protein kinase and Beclin 1 in mediating autophagy. Circ Res 100: 914-922, 2007. https://doi.org/10.1161/01.res.0000261924.76669.36

NISHINO Y, WEBB IG, DAVIDSON SM, AHMED AI, CLARK JE, JACQUET S, SHAH AM, MIURA T, YELLON DM, AVKIRAN M, MARBER MS: Glycogen synthase kinase-3 inactivation is not required for ischemic preconditioning or postconditioning in the mouse. Circ Res 103: 307-314, 2008. https://doi.org/10.1161/circresaha.107.169953

NGUYEN G: Renin and prorenin receptor in hypertension: what's new? Curr Hypertens Rep 13: 79-85, 2011. https://doi.org/10.1007/s11906-010-0172-9

NGUYEN G, DELARUE F, BURCKLE C, BOUZHIR L, GILLER T, SRAER JD: Pivotal role of the renin/prorenin receptor in angiotensin II production and cellular responses to renin. J Clin Invest 109: 1417-1427, 2002. https://doi.org/10.1172/jci0214276

PENG H, JENSEN DD, LI W, SULLIVAN MN, BULLER SA, WORKER CJ, COOPER SG, ZHENG S, EARLEY S, SIGMUND CD, FENG Y: Overexpression of the neuronal human (pro)renin receptor mediates angiotensin IIindependent blood pressure regulation in the central nervous system. Am J Physiol Heart Circ Physiol 314 : H580-H592, 2018. https://doi.org/10.1152/ajpheart.00310.2017

POTZ BA, SABE AA, ELMADHUN NY, CLEMENTS RT, ABID MR, SODHA NR, SELLKE FW: Calpain inhibition modulates glycogen synthase kinase 3beta pathways in ischemic myocardium: A proteomic and mechanistic analysis. J Thorac Cardiovasc Surg 153: 342-357, 2017. https://doi.org/10.1016/j.jtcvs.2016.09.087

RAMKUMAR N, STUART D, ABRAHAM N, KOHAN DE: Nephron prorenin receptor deficiency alters renal medullary endothelin-1 and endothelin receptor expression. Physiol Res 67 (Suppl 1): S127-S136, 2018. https://doi.org/10.33549/physiolres.933809

RIBEIRO AA, AMORIM RP, PALOMINO ZJ, DE PAULA LIMA M, MORAES-SILVA IC, SOUZA LE, PESQUERO JL, IRIGOYEN MC, CASARINI DE: (Pro)renin receptor expression in myocardial infarction in transgenic mice expressing rat tonin. Int J Biol Macromol 108: 817-825, 2018. https://doi.org/10.1016/j.ijbiomac.2017.10.179

RIEDIGER F, QUACK I, QADRI F, HARTLEBEN B, PARK JK, POTTHOFF SA, SOHN D, SIHN G, ROUSSELLE A, FOKUHL V, MASCHKE U, PURFURST B, SCHNEIDER W, RUMP LC, LUFT FC, DECHEND R, BADER M, HUBER TB, NGUYEN G, MULLER DN: Prorenin receptor is essential for podocyte autophagy and survival. J Am Soc Nephrol 22: 2193-2202, 2011. https://doi.org/10.1681/asn.2011020200

ROMERO M, SABATE-PEREZ A, FRANCIS VA, CASTRILLON-RODRIGUEZ I, DIAZ-RAMOS A, SANCHEZFEUTRIE M, DURAN X, PALACIN M, MORENO-NAVARRETE JM, GUSTAFSON B, HAMMARSTEDT A, FERNANDEZ-REAL JM, VENDRELL J, SMITH U, ZORZANO A: TP53INP2 regulates adiposity by activating beta-catenin through autophagy-dependent sequestration of GSK3beta. Nat Cell Biol 20: 443-454, 2018. https://doi.org/10.1038/s41556-018-0072-9

SHIBAYAMA Y, FUJIMORI T, NGUYEN G, HIROSE T, TOTSUNE K, ICHIHARA A, KITADA K, NAKANO D, KOBORI H, KOHNO M, MASAKI T, SUZUKI Y, YACHIDA S, NISHIYAMA A: (Pro)renin receptor is crucial for Wnt/beta-catenin-dependent genesis of pancreatic ductal adenocarcinoma. Sci Rep 5: 8854, 2015. https://doi.org/10.1038/srep08854

SINGH KK, YANAGAWA B, QUAN A, WANG R, GARG A, KHAN R, PAN Y, WHEATCROFT MD, LOVREN F, TEOH H, VERMA S: Autophagy gene fingerprint in human ischemia and reperfusion. J Thorac Cardiovasc Surg 147: 1065-1072.e1, 2014. https://doi.org/10.1016/j.jtcvs.2013.04.042 
THIRUNAVUKKARASU SELVARAJU V, TAPIAS L, SANCHEZ JA, PALESTY JA, MAULIK N: Protective effects of Phyllanthus emblica against myocardial ischemia-reperfusion injury: the role of PI3-kinase/glycogen synthase kinase 3beta/beta-catenin pathway. J Physiol Biochem 71: 623-633, 2015. https://doi.org/10.1007/s13105-015-0426-8

YAHIRO E, IDEISHI M, WANG LX, URATA H, KUMAGAI K, ARAKAWA K, SAKU K: Reperfusion-induced arrhythmias are suppressed by inhibition of the angiotensin II type 1 receptor. Cardiology 99: 61-67, 2003. https://doi.org/10.1159/000069722

YELLON DM, HAUSENLOY DJ: Myocardial reperfusion injury. N Engl J Med 357: 1121-1135, 2007. https://doi.org/10.1056/nejmra071667

ZHOU A, CARRELL RW, MURPHY MP, WEI Z, YAN Y, STANLEY PL, STEIN PE, BROUGHTON PIPKIN F, READ RJ: A redox switch in angiotensinogen modulates angiotensin release. Nature 468: 108-111, 2010. https://doi.org/10.1038/nature09505

ZHOU H, ZHANG Y, HU S, SHI C, ZHU P, MA Q, JIN Q, CAO F, TIAN F, CHEN Y: Melatonin protects cardiac microvasculature against ischemia/reperfusion injury via suppression of mitochondrial fission-VDAC1-HK2mPTP-mitophagy axis. J Pineal Res 63: 2017. https://doi.org/10.1111/jpi.12413

ZHU B, SUN Y, SIEVERS RE, BROWNE AE, PULUKURTHY S, SUDHIR K, LEE RJ, CHOU TM, CHATTERJEE K, PARMLEY WW: Comparative effects of pretreatment with captopril and losartan on cardiovascular protection in a rat model of ischemia-reperfusion. J Am Coll Cardiol 35: 787-795, 2000. https://doi.org/10.1016/s0735-1097(99)00592-6 